\title{
Three Controversies
}

Three Case Studies - the City of David / Silwan, the Church of the Holy Sepulchre, and the Temple Mount / Haram al-Sharif-lead us through the journey in which scientific procedures and religious aspirations have led to the binary forces of scholarly agreement and dissonance, as well as of political alliance and conflict. First, as the place where Jerusalem's earliest settlement has been documented, the City of David has been turned into a stage where the Hebrew Bible is reenacted, using archaeology as a tool. Below the houses of Palestinian residents of Silwan, its numerous cavities and tunnels-and their alleged holiness-have recently evolved into one of Jerusalem's most contested sites. Second, above the ground, the standing monument of the Church of the Holy Sepulchre has served as Jerusalem's primary Christian place of worship and pilgrimage, as well as one of the most desired places of scientific exploration. It has been on the front line of Christian denominational disputes, as well as a locus of negotiations with the Jewish, Muslim, and, more recently, the Israeli and Palestinian communities. Finally, Jerusalem's main acropolis and the city's focal holy site, the Temple Mount, or the Haram al-Sharif, has served as an active place of worship and pilgrimage from antiquity to the present. Here we can retrace how the Jewish, Christian, and Muslim faiths continue to build upon each other physically and spiritually, and how these interdependent communities have been caught up in the religio-political struggle. More so than any other holy compound, the Temple Mount / Haram al-Sharif has been used as a stage to manipulate heritage for the purpose of religious and nationalistic agendas of regional and international impact. These three controversies encapsulate the challenges of Jerusalem's archaeological heritage and demonstrate the entanglement of science and ideology. 



\section{7 \\ The City of David / Silwan}

On top of Wadi Hilwe Street, two signs direct the visitor to explore the neighborhood. One of them reads Silwan; the other, City of David. Both names appear in three different languages, Hebrew, Arabic, and English, an apparent attempt to balance or disguise a completely unruly situation. Amid a population of about fifty thousand Palestinian villagers live some seven hundred Jewish settlers, a cohabitation that is facilitated through barbed wires, electric fences, guard booths, and towers, as well as dozens of security cameras and personnel, which may occasionally help prevent some violent confrontation, but more surely emphasize and deepen the rift and animosity between the original residents and the Jewish settlers, who started to move into the neighborhood in $1991{ }^{1}$

Silwan is the name of the village. It originated on Ras al-Amud, on the southwest slope of the Mount of Olives, and at the beginning of the twentieth century, gradually began expanding across the Kidron Valley (to locals also know as Wadi Sitti Maryam or the Valley of St. Mary). It eventually incorporated all of the Southeast Hill, which today is considered the Wadi Hilwe neighborhood (see figure 27). The village of Silwan is hundreds of years old; according to tradition, it originated at the time of Salah al-Din in the twelfth century. ${ }^{2}$ City of David-in Hebrew, Ir David, a biblical epithet (2 Samuel 5:9), which most likely indicated David's citadel—was a term introduced by French archaeologist Raymond Weill, who conducted the first open-air excavations on the Southeast Hill, in 1913-14. The name was rarely used, however, until Yigal Shiloh began to direct the first Israeli exploration of the hill, in 1978. Most excavators till then preferred the name Ophel, another biblical name used to describe the area immediately to the south of the Temple Mount platform. ${ }^{3}$ 


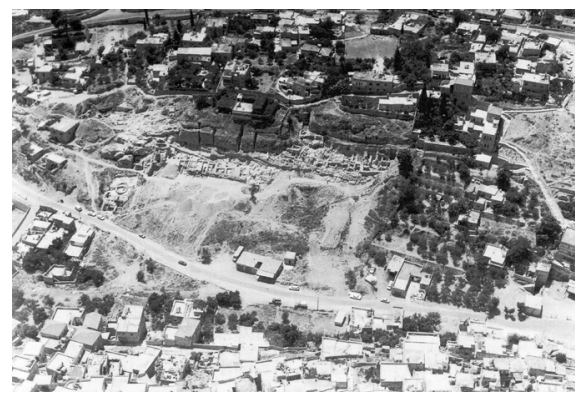

FIGURE 27. The densely built-up area of the Palestinian neighborhood Silwan, in the midst of which the City of David Archaeological Park was established. Courtesy of the Institute of Archaeology, The Hebrew University of Jerusalem.

Silwani villagers live in modest, often improvised housing - a mix of stone, concrete, and steel construction-built alongside lanes and roads, some of which are unpaved. The City of David Visitors Center, the surrounding archaeological park, as well as the settlers' houses, in contrast, are beautifully built and maintained, speckled amid the Palestinian village and connected by newly paved streets. The gardening and numerous Israeli flags make for additional unmistakable attributes of the recent urban transformations initiated and financed by both the Jerusalem municipality and Elad. Tourist trails lead visitors through well-designed spaces, some of which are above ground, but most of which are expanding underneath the private and public buildings of the Silwan neighborhood. Since the mid-199os, millions of visitors have explored the excavated features, treading in the footsteps of dozens of adventurous explorers on a journey to discover physical remains embodying the biblical narrative. ${ }^{4}$ Two realities seem to be ignored, however, by most visitors: the many centuries of historical legacy that link the Palestinian Silwani to this place and the lack of archaeological data on the Southeast Hill supporting the biblical narrative of King David's conquest and rule in the city.

\section{DIGGING UP THE BIBLE}

The Southeast Hill is the most excavated place in Jerusalem, with a history of more than 150 years of exploration. Ironically, the most extensive and intrusive excavations coincided with the most significant and rapid growth of the modern village, following Israel's 1967 capture of East Jerusalem. The archaeological exploration has been motivated from the beginning by the desire to find physical traces of the biblical narrative, prioritizing this mission over the concern for the residents who live on the land. The quality of private and public life in Silwan, particularly over the last two decades, has been increasingly compromised by excavation and the development of the tourist industry. Though highly successful in attracting millions of visitors, much of this recent activity is ideologically and politically motivated and cannot be justified on scientific grounds. This 
entanglement of archaeology, religion, and ideology has fueled the tension between the Jewish settlers and the original Silwani residents, between the Israeli and the Palestinian public.

An ongoing debate about the significance of the continuous flow of supposedly important discoveries related to the biblical narrative, the political implications of the growing settler presence, and the eviction of Palestinian residents has flooded the media and produced numerous erudite articles. One of the lacunae in the scholarly discourse is the apparent lack of communication between archaeologists and professionals or researchers in other fields. The literature that addresses the social and political aspects of the issue - the impact of archaeological activities and tourism development on Silwan's residents, the political conflict, and the territorial and demographic realities of Jerusalem-is mostly written by social and political scientists or by architects and urban planners, but it doesn't pay much attention to the actual archaeological data. The scholarly discourse of archaeologists focuses primarily on the tangible data-or lack thereof-of their work, but without discussing the practical and political implications of the excavation, preservation, and development initiatives that are being carried out, both above and below ground. ${ }^{5}$

What have 150 years of archaeological survey and excavation on the Southeast Hill revealed? Which were the most significant expeditions and the most important discoveries? The countless excavations, the innumerable finds, and finally the discrepancy between scholarly consensus and media coverage make it difficult, even sometimes for the experts themselves, to differentiate between sensational discoveries and genuinely significant finds.

Numerous excavations have been carried out on the Southeast Hill since the beginning of exploration in the mid-nineteenth century (see figure 28). Our knowledge has expanded greatly, and scientific methods have made tremendous progress. Yet the primary motivation to dig up the relatively small area has not changed since the Ottoman period: uncovering the physical traces of the biblical narrative.

Some of the most significant discoveries on the Southeast Hill were made under Ottoman rule, during the first decades of archaeological activity. Those include the water systems of the Bronze and Iron Age and the Siloam Tunnel and its inscription, the Herodian Siloam Pool, the Theodotus synagogue inscription, and the Byzantine Siloam Church. ${ }^{6}$ It is interesting to note that at the beginning of the twentieth century, both scholarly circles and the wider public were alike able to differentiate between scientific endeavors and aimlessly conducted and spiritually motivated treasure hunts. The legendary Parker expedition, which sought to uncover the Ark of the Covenant and Solomon's treasures, invited Father Vincent from the École biblique to provide a scientific framework to an otherwise unreasonable project. The irrational nature of the enterprise, however, was quite transparent to 


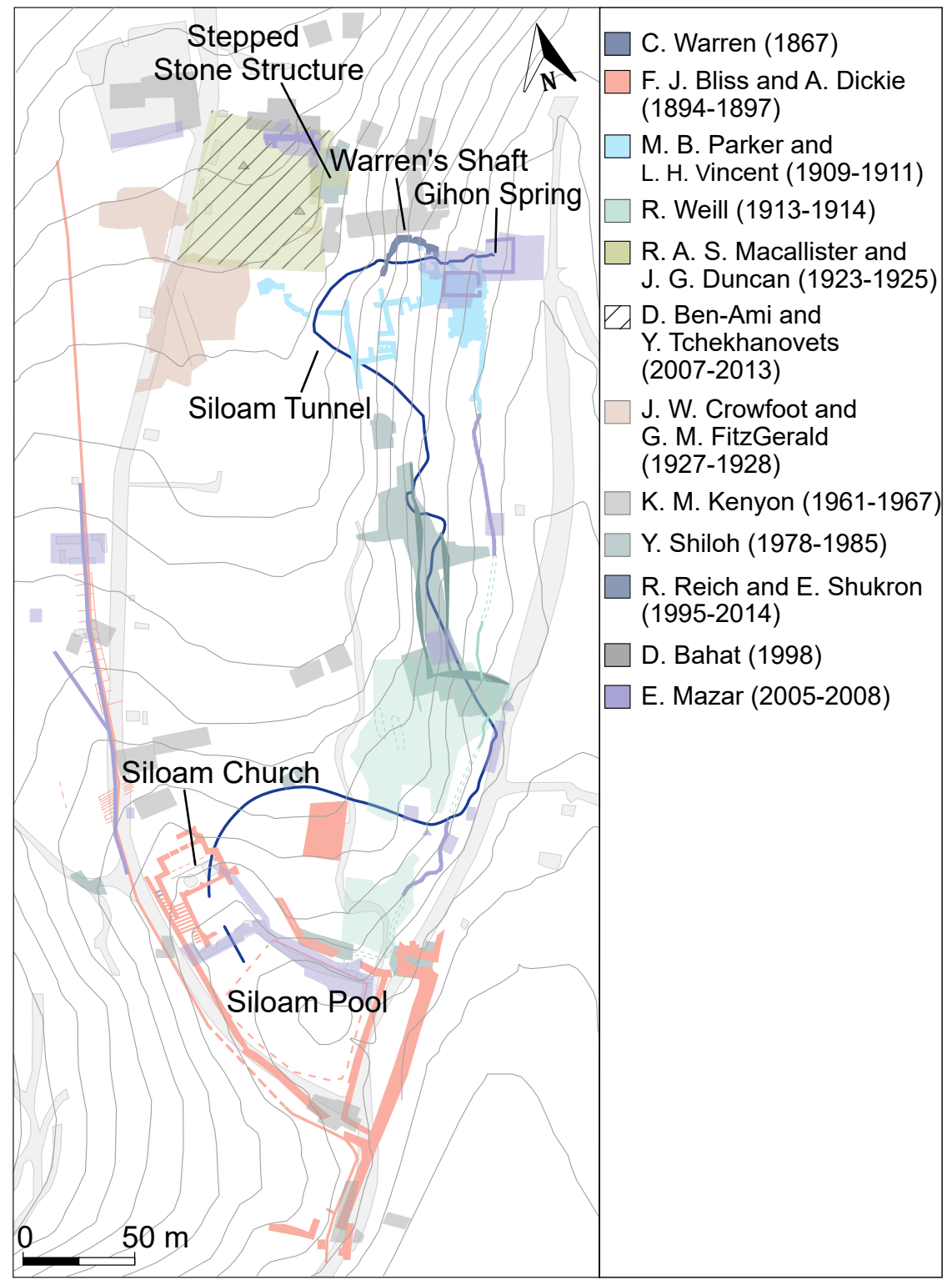

FIGURE 28. City of David, areas of excavation. Redrawn by Franziska Lehmann, after: Reich, Excavating the City of David. Where Jerusalem's History Began, plates 11, 57, 74 and 83. 
all. Given local and even international pressures, the excavation could ultimately not be completed. ' Expeditions conducted by Warren and by Bliss and Dickie under the auspices of the PEF, and even Weill's work, carried out on behalf of Baron Edmond de Rothschild, on the other hand, gained wide acclaim and some of their results have impacted our understanding of Jerusalem's early history.

The two theories established during those early years of exploration that had a significant influence on all further archaeological work carried out in the city were that Jerusalem's earliest settlement began on the Southeast Hill, outside of the Old City boundaries, and that King David used the underground tunnel system linked to a vertical sinkhole known as Warren's Shaft to conquer the city from the Jebusites. Recent excavations established that the earliest finds documenting a prehistoric presence on the Southeast Hill can be dated to as early as the Epipaleolithic period (22,000 B.P.-9,500 B.C.E.). ${ }^{8}$ But these excavations also proved that Warren's Shaft had been inaccessible during the period attributed to David's conquest of Jerusalem. ${ }^{9}$

Under British rule, there were two especially significant expeditions, one led by R. A. S. Macalister and J. G. Duncan in 1923-25, and the other by J. W. Crowfoot and G. M. FitzGerald in 1927. ${ }^{10}$ The chief discovery made during this period pertains to the Stepped Stone Structure, which at the time was only partially exposed. It was believed to represent the fortress of Zion mentioned in the Bible (2 Samuel 5:7), built by the Jebusites and taken over by the Israelites around 1000 B.C.E. ${ }^{11}$ As a result of the excavations carried out in the 1960 s and 1970s, which gradually exposed the remainder of the structure, numerous chronological assessments and interpretations have been proposed. Chronological distinctions are made between the core (the substructural terraces) and the surface, commonly referred to as the Stepped Stone Mantle. Suggested dates range between the Bronze Age (fourteenth to thirteenth centuries B.C.E.) and the Hellenistic period (second century B.C.E.). ${ }^{12}$ Though the original function and appearance of the structure remain unresolved, most scholars are reluctant to detach themselves completely from the biblical reference to the fortress of Zion, suggesting that the Stepped Stone Structure served as a substructure of a public building, possibly a palace or administrative complex. ${ }^{13}$

Despite the fact that Kathleen Kenyon's work, which was carried out during the period of Jordanian rule, is usually associated with significant scientific advances, including the introduction of stratigraphic excavation, it is often ignored that she had little interest in post-biblical periods. In addition to exposing various sections of the Bronze and Iron Age defense system, as well as changes or additions introduced during the Hellenistic period, she excavated an area that she assumed to be cultic in nature, including two masseboth (standing stones), a favissa (repository pit of votive objects), and a libation altar. ${ }^{14}$ Though still recognized for her meticulous and progressive work, many of her interpretations have been refuted over 
the years, most importantly, her view that the city remained small throughout the Iron Age. ${ }^{15}$

The most intensive period of exploration on the Southeast Hill began shortly after Israel captured East Jerusalem in 1967. Since then, numerous excavations have been carried out involving faculty from most major Israeli universities (Hebrew University, Haifa University, and Tel Aviv University) as well as employees from the IAA. ${ }^{16}$ The first major project was directed by Yigal Shiloh, which exposed further components of the Bronze and Iron Age water and defense system, dwellings from the Iron Age that document the last period of occupation prior to the Babylonian conquest of the city in the sixth century B.C.E. and traces of the fire that both destroyed and preserved various features of Iron Age II material culture. ${ }^{17}$ Eilat Mazar excavated the so-called Large Stone Structure, which she thought formed part of King David's palace, a theory that has not gained support in the academic community. ${ }^{18}$ The longest and most extensive excavation was conducted by Ronny Reich and Eli Shukron, which provided a completely new understanding of the city's early water and defense system. This not only disproved Warren's long-standing theory of David's conquest but also showed that during the Middle Bronze Age II, the Gihon Spring was located within the city boundaries and was protected by a monumental wall and tower. ${ }^{19}$ Another noteworthy discovery was the so-called Siloam Pool, a large stepped pool, built and used prior to the destruction of the Second Temple. ${ }^{20}$ According to the excavators, it was used by pilgrims for ritual purification before visiting the Temple and served as the site of Jesus's healing of the blind man mentioned in the New Testament (John 9); neither interpretation has gained much recognition among scholars. ${ }^{21}$

Another large-scale project, still ongoing, are the Givati Parking Lot excavations directed by Doron Ben-Ami and Yana Tchekhanovets. These excavations have shown that the area served as a residential neighborhood, with only short interruptions, from the eighth century B.C.E. through the tenth century C.E. The most important architectural finds include a Roman peristyle villa (late third to fourth centuries C.E.) and a large building (dated to the fifth to seventh centuries C.E.) that is presumably the "seat of the Byzantine official representative." ${ }^{22}$

\section{SCHOLARLY CONSENSUS AND CONTROVERSY}

Though the majority of archaeologists digging on the Southeast Hill have been in agreement about the desired focus of exploring the Southeast Hill-bringing the written narratives of the Hebrew Bible, Flavius Josephus, and the New Testament into dialogue with the material remains-most discoveries, in particular those potentially relevant to the biblical accounts, have resulted in a disarray of interpretations. There are, however, several noteworthy discoveries whose meaning scholars agree about. The location of Jerusalem's earliest settlement on the Southeast Hill 
is quite clear, as is the dating of the earliest flint tools, the first dwellings, and the city walls. No one seems to challenge the results of the excavations exposing Jerusalem's Middle Bronze Age fortification and water system. No major discrepancies exist in scholarly interpretations regarding the late Iron Age settlement and dwellings destroyed during the Babylonian conquest in the late sixth century B.C.E. It is also unlikely that the recent discoveries of the Roman peristyle villa, the Byzantine mansion, and Abbassid dwellings will lead to scholarly controversies. These facts seem straightforward, and no major historical revisions are necessary.

It is documented that the Gihon Spring and Siloam Pool remained important landmarks throughout the early Islamic, medieval, and late Islamic periods. ${ }^{23}$ The Siloam Pool is depicted on several Crusader maps of the city, and there is archaeological evidence that the Gihon Spring was unblocked sometime during the twelfth or thirteenth century. ${ }^{24}$ Despite the fact that even the earliest excavations documented artifacts from the Mamluk period, archaeologists have paid remarkably little attention to post-Byzantine structures. ${ }^{25}$ It is difficult to assess how many of these later finds were discarded and perhaps bulldozed, a situation that would not be so different from other areas within the city and more generally in the region.

Less unison seems to exist among scholars regarding religious sites and monuments. In spite of the numerous late Iron Age figurines and other possible cult paraphernalia uncovered, there is no real agreement about the cultic use of this area, as the Southeast Hill does not appear to have ever served a central role in the city's religious public life. No concrete evidence for the existence of a house of worship, other than the first-century C.E. synagogue inscription, which was not found in situ, has been documented.

Among the more controversial discoveries are sites or monuments that have been linked to biblical descriptions, such as the Stepped Stone Structure, the Large Stone Structure, Warren's Shaft, and the Siloam inscription. The most debated issue in the context of the Southeast Hill, however, concerns the limited amount of material remains dating to the eleventh and tenth centuries B.C.E. (the time of the transition between Iron Age I and Iron Age II), the period believed to correspond to the reigns of Kings David and Solomon, the time of the United Kingdom of Judah and Israel. One may easily understand how an unusual artifact or structure can lead to heated discussions and conflicting reconstructions and theories, so it is peculiar that, in fact, the most disputed topic about the Southeast Hill excavations is the lack of finds. Of course, one of the main principles of the field of archaeology is that the absence of evidence is no evidence for absence. That is, if something was not found, that doesn't mean that it was never there. The possibilities of interpretation are more varied and flexible when no tangible remains have survived. Beyond the limited extant material data for the tenth century B.c.E., the difficulty in reconstructing the city during this period stems from the absence of contemporary 
historical records. The biblical passages describing David's and Solomon's Jerusalem were written hundreds of years after the events they describe, portraying the monarchy from a later perspective. At one extreme, some scholars believe that the historicity of these accounts is minimal or even completely absent. ${ }^{26}$ They argue that the biblical narrative was influenced by religious perceptions and political agendas, largely inflating the narrative to portray a more glorious and powerful rule. ${ }^{27}$ On the other extreme are those conservative scholars who rely on the biblical account as their primary guidance in understanding historical events and identifying archaeological remains. ${ }^{28}$ They put forth various explanations as to why the material records are so limited. One is the argument that the people of the late Iron Age continued to use the well-built Middle Bronze Age structures, and since the period was relatively peaceful, there was no need to construct new fortifications and water systems. Another explanation is that the numerous destructions that the city suffered throughout the centuries, each one followed by reconstruction, sometimes completely eliminated earlier layers and traces of occupation. An additional argument is that in Jerusalem buildings are made of stone and thus each new construction is built directly on bedrock, rather than on earlier courses of brick, as is the case at most biblical tells in the region. A variety of valuable arguments have been put forward to explain the paucity of archaeological remains, and many thoughtful theories have been developed regarding Jerusalem in the eleventh and tenth centuries B.C.E. and the relationship between the Southeast Hill and the biblical narrative. No ultimate proof, however, has been presented, and the discourse continues.

\section{ARCHAEOLOGY, RELIGION, AND POLITICS ENTANGLED}

The professional and ideological zeal of most archaeologists who have explored the Southeast Hill often impeded productive contact with the local Jerusalem communities - especially the inhabitants of Silwan. A distinct tone of disdain can be perceived in Warren's account of the condition of the village and his description of its residents as "a lawless set, credited with being the most unscrupulous ruffians in Palestine." ${ }^{29}$ Throughout the early decades of archaeological activity, the interaction between Western archaeologists and locals was quite limited and often unfriendly.

It was not until 1981, however, that tensions between archaeologists and Jerusalem residents-this time not the local villagers, but members of the ultra-Orthodox community - escalated to the point that police had to interfere and legal action had to be taken. The battle waged by excavation director Yigal Shiloh against Atra Kadisha, which claimed that Jewish graves were being dug up, was perceived by many not only as the struggle of Israel's archaeologists advocating the freedom of science 
and knowledge but also as exemplary of the great rift between the objectives of Israel's secular segment of society versus the religious and ultra-Orthodox sectors. ${ }^{3 \circ}$

The conflict resulting from archaeological activity would reach entirely new dimensions when the objectives of the excavation and associated tourism initiatives started to be part of an official municipal program in which religious and political agendas rather than scientific inquiries began to dictate the scope and nature of the work. In 1995, the Jerusalem Municipality celebrated the three thousandth anniversary of David's conquest of the city, initiating a new chapter in the archaeological exploration of the hill..$^{31}$ The decision was made to conduct even more massive excavations to connect the different sites and to develop them into a major tourist attraction.

At this point, Elad turned into one of the main actors involved in facilitating this overhaul. One fact that is ignored by many, however, is that Elad-which is the primary sponsor of the excavations conducted in Silwan today-was established as a foundation several years prior to its involvement with archaeology.32 Originally, Elad's exclusive goal was that of renewing the Jewish presence in Silwan and East Jerusalem more generally, particularly through the acquisition of Palestinian homes. Their early years of activity in the neighborhood, in fact, caused major clashes with the archaeological community, who opposed their ambitious building projects, which would unavoidably endanger archaeological heritage. The intended construction of two hundred housing units for Jewish citizens in Silwan, planned by Elad jointly with the Ministry of Housing in 1992, led to protests by a group of Israeli archaeologists-including Israeli academics and employees of the IAA - and several legal battles, which ultimately prevented the construction. ${ }^{33}$

Following these initial hostilities, instead of building new homes, Elad's strategy began to shift more heavily toward appropriating homes of Palestinian families. Furthermore, rather than endangering the area's antiquities and thus operating in opposition to the archaeological community, Elad transformed itself into Silwan's primary archaeological sponsor, financing most of the excavations as well as the associated tourism and education activities, gradually turning itself into the city's most powerful NGO. Since 2002, Elad has managed the City of David Archaeological Park, an authority that has been sanctioned by the Jerusalem Municipality, the IAA, and the INPA. ${ }^{34}$ Cooperation between Elad and the different governmental institutions has been smooth and thriving ever since. In recent years, the City of David Archaeological Park has indeed turned into Jerusalem's most popular heritage site and one of the country's most visited tourist attractions (see figure 29). In spite of Elad's increasing success in terms of fund raising, home appropriations, excavation, conservation and reconstruction projects, education and outreach activities, tourist development, and-perhaps most importantly_full governmental approval, support, and cooperation, numerous individuals as well as communities and organizations have voiced criticism regarding its activities. ${ }^{35}$ 


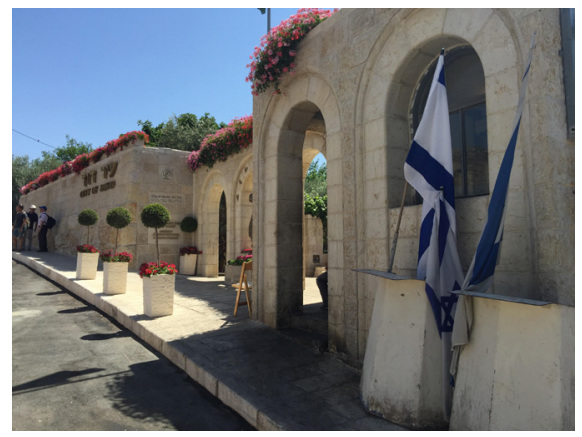

FIGURE 29. Entrance to the City of David Archaeological Park. Photo by Katharina Galor.

The most active and effective group to challenge Elad's mission in the City of David is Emek Shaveh, which is invested in informing the public of how political and religious ideology is implicated in the current excavation and tourist initiatives in Silwan to the detriment of its Palestinian inhabitants. ${ }^{36}$ Established and directed by two Israeli archaeologists, this group interacts closely with the Wadi Hilwe Information Center, a Palestinian organization whose mission is to build a strong, well-informed, and involved Palestinian community and to provide educational and recreational courses for young people. ${ }^{37}$

In its criticism of Elad's activities, Emek Shaveh states that "an archaeological find should not and cannot be used to prove ownership by any one nation, ethnic group or religion over a given place. Moreover the term 'archaeological site' does not only refer to excavated layers of a site but also to its present day attributes-the people living in it or near it, their culture, their daily life and their needs." ${ }^{38}$ In numerous publications, Emek Shaveh has established how various recent initiatives conducted under the sponsorship of Elad have manipulated archaeological findings in Silwan to highlight the Jewish narrative, while ignoring both the histori$\mathrm{cal}$ and cultural legacy-as well as the human rights—of its Palestinian residents. Emek Shaveh has further demonstrated how Elad has compromised scientific and professional standards for its ideological goals, entailing the Judaization of a Palestinian neighborhood..$^{39}$

Emek Shaveh's outreach efforts, including alternative archaeological tours of the City of David, booklets, regular newsletters, and an active website, are mostly geared toward educators, journalists, and politicians, some local, but most international. Their activities have gained some momentum among the general public, but they are at a clear disadvantage in comparison to Elad's outreach efforts, as Elad has millions of dollars at their disposal, as well as marketing strategies that have proved most effective in the development of other entertainment parks, both nationally and internationally. Additionally, Elad creates facts on the ground that can be consumed, by excavating and restoring antiquities, by acquiring Palestinian 
homes, by building homes for Jewish citizens, and by constructing residential and tourist infrastructure. Emek Shaveh, on the other hand, is mostly limited to raising awareness among the public and providing information to those willing to examine the state of affairs critically. Reaching the masses with popular myth and tradition by using effective and highly entertaining visual and sound stimuli-as practiced by Elad-is generally more appealing than Emek Shaveh's approach of focusing on analytical and critical commentaries that deal with the distressing local and regional conflict.

It is undeniable that, since the mid-1990s, archaeological initiatives on the Southeast Hill can no longer be separated from the political conflict between Israelis and Palestinians, as reflected in the latter's struggle to maintain or appropriate land and to ascertain their entitlement to living in Silwan. No one living, working, or even visiting Silwan can be indifferent to the ideological weight of archaeology and tourism in this sector of the city.

Since the mid-1990s, all archaeological excavations in Silwan have been linked directly with various other municipally and governmentally controlled activities, including tourist development, discriminatory housing and building policies for Palestinians, house demolitions, and the procurement of homes for Jewish settlers. These activities have progressed simultaneously and with a common goal: to mark the ground of a continued Jewish presence, both historically and territorially, and to justify Israeli's occupation of East Jerusalem. And since 2002, when Elad took on the official role of managing the City of David Archaeological Park, these investments have seemed to be more efficiently coordinated and irrevocably entangled, despite efforts to disguise excavation and tourist development as scientifically framed and culturally motivated.

\section{LIGHT AT THE END OF THE TUNNEL?}

In 1999 Reich and Shukron published an article in a popular archaeology journal entitled "Light at the End of the Tunnel: Warren's Shaft Theory of David's Conquests Shattered." 40 This publication, and the excavations on which it was based, had the potential to liberate the Southeast Hill from its longstanding burden to provide the physical proof of the biblical narrative of King David's conquest. For nearly 150 years, Warren's theory that a vertical sinkhole in proximity of the Gihon Spring was used by the Israelites to conquer Jerusalem from the Jebusites was widely accepted among scholars and was a magnet for anyone visiting Silwan. Reich and Shukron's excavations established that Warren's Shaft, was not accessible until about two hundred years after the legendary conquest, dated to around 1000 B.C.E. They also showed that the site's most impressive features, including fortifications and water installations, were built during the Middle Bronze Age, long before King David's and King Solomon's reigns. But despite the fact that the theory 
of David's conquest via Warren's Shaft has lost its credibility, the rapidly expanding underground facilities have met with growing interest and enthusiasm among tourists and visitors. Those facilities, consisting of natural cavities and fissures as well as of built tunnels and halls, many of them carved out only in recent years, have proved to be suitable grounds for physically reenacting the adventurism of the city's past and present explorers and experiencing the mysteries of the biblical and historical narratives set in Jerusalem.

This potential has been recognized and used in the context of the new archaeological circuit that provides a direct link between the City of David in Silwan and the Western Wall Plaza in the Jewish Quarter. Referred to as the Herodian Street and Tunnel, ${ }^{41}$ the underground route begins at the Siloam Pool near the southern tip of the City of David and resurfaces at the Givati Parking Lot. From there, visitors can continue through another underground segment leading under the Old City walls and emerge via a Herodian street running under Robinson's Arch and leading to the southwest corner of the Temple Mount. Other than the area near the Siloam Pool, which consists of a paved esplanade and two parallel segments of stepped streets, most of the route consists of a drainage channel, which had been exposed (in short sections) in various expeditions conducted over the last century. ${ }^{42}$ This system was designed to carry the wastewater-rainwater runoff and sewage-first down to the Central Valley and then southward, debouching outside the city. Though the circuit is advertised as the path trod by pilgrims of the Second Temple period ascending from the City of David to the Temple Mount, only few sections of the original pavement overlying the channel are preserved (see figure 30). ${ }^{43}$ Neither the original path nor its date can be fully and accurately reconstructed. ${ }^{44}$ The clearing of this channel necessitated the construction of extremely complicated and powerful support structures made of cement and steel piles-no doubt at the cost of millions of dollars-and yet the futility of this project from an archaeological point of view is obvious, perhaps more so than any other excavation conducted in Jerusalem. The recent excavations have revealed nothing that was not known prior nor did they promise to provide any useful data or enhance the knowledge regarding the chronology, function, or topography of the area. Its purpose was to strengthen the Jewish narrative of pilgrimage to the Holy City, as well as to create both a tangible and ideological link between the First and Second Temple periods, between the City of David and the Temple Mount, and finally between the Israelite and Jewish past and the Israeli present. Strengthening the Jewish ties to the neighborhood and undermining the position of Palestinian residents, their historical roots and their current civic rights, are interrelated realities that lead to tangible facts both below and above the ground, sealing the irreversible reality of Israeli occupation.

What does the light we see at the end of the recently excavated tunnels illuminate? Which scholarly riddles were elucidated, if the theory of David's legendary 


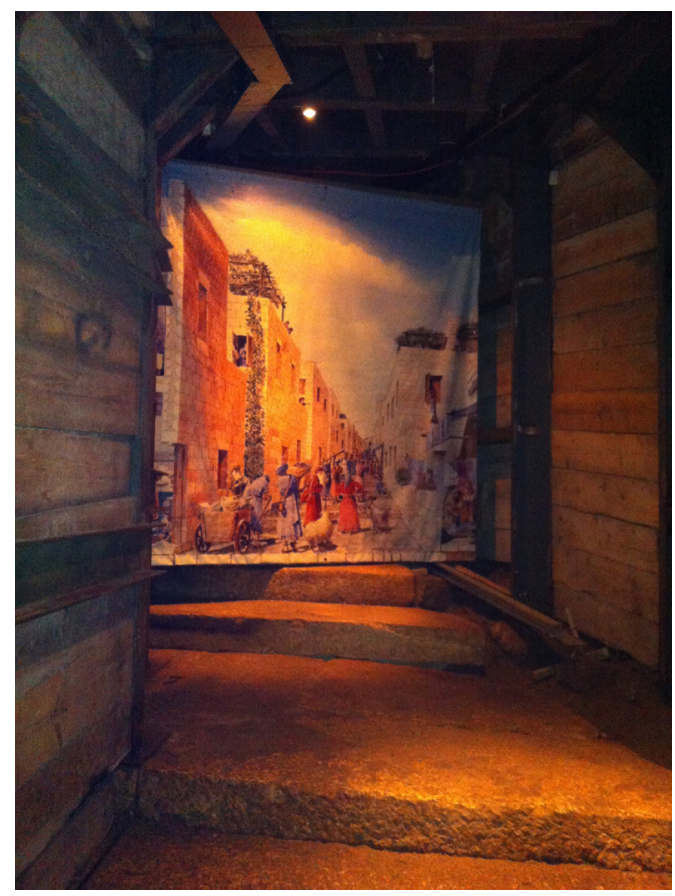

FIGURE 30 . Herodian street section with artist reconstruction of Second Temple period pilgrimage scene. Photo by Katharina Galor.

conquest was debunked? And how do these mobilize the interest and attention among hundreds and thousands of tourists annually? The archaeological findings in Silwan certainly carry an intrinsic value and are instructive in relation to Jerusalem's early history, in particular regarding the city's water and fortification systems. But in spite of the expeditions' persistent focus on early periods and their minor engagement with post-Byzantine remains, the significance of the discoveries with regard to the biblical narrative is limited, if not completely absent, for the periods associated with the rules of David and Solomon. It appears that the holiness that the City of David holds for some is recent, ideologically motivated, and not anchored in the tradition of an ancient sanctuary. 